\title{
Correction to: Cut-off points between pain intensities of the postoperative pain using receiver operating characteristic (ROC) curves
}

\author{
Sooyoung Cho' ${ }^{1}$, Youn Jin Kim ${ }^{1 *}$, Minjin Lee ${ }^{2}$, Jae Hee Woo ${ }^{1}$ and Hyun Jung Lee ${ }^{1}$
}

\section{Correction to: BMC Anesthesiol 21, 29 (2021)}

https://doi.org/10.1186/s12871-021-01245-5

Following publication of the original article [1], the authors report an error in the Method section. The formula used for determining the cut-off points from the receiver operating characteristic (ROC) curves was published incorrectly, so the authors correct the error. The formula was published as below originally.

$$
d=\sqrt{(1-\text { sensitivity })^{2}+(1-\text { sensitivity })^{2}}
$$

The authors correct this as below [2].

$$
d=\sqrt{(1-\text { sensitivity })^{2}+(1-\text { specificity })^{2}}
$$

\section{Author details}

'Department of Anesthesiology and Pain Medicine, Ewha Womans University College of Medicine, 260, Gonghang-daero, Gangseo-gu, Seoul 07804, Republic of Korea. ${ }^{2}$ Department of Anesthesiology and Pain Medicine, Ewha Womans University Medical Center Mokdong Hospital, Seoul, South Korea.

\author{
References \\ 1. Cho S, Kim YJ, Lee M, Woo JH, Lee HJ. Cut-off points between pain \\ intensities of the postoperative pain using receiver operating character- \\ istic (ROC) curves. BMC Anesthesiol. 2021;21:29. https://doi.org/10.1186/ \\ s12871-021-01245-5. \\ 2. Hajian-Tilaki K. Receiver operating characteristic (ROC) curve analysis for \\ medical diagnostic test evaluation. Caspian J Intern Med. 2013;4:627-35.
}

\section{Publisher's Note}

Springer Nature remains neutral with regard to jurisdictional claims in published maps and institutional affiliations.

Published online: 16 July 2021

The original article can be found online at https://doi.org/10.1186/s12871021-01245-5.

\footnotetext{
*Correspondence: ankyj@ewha.ac.kr

1 Department of Anesthesiology and Pain Medicine, Ewha Womans University College of Medicine, 260, Gonghang-daero, Gangseo-gu, Seoul 07804, Republic of Korea

Full list of author information is available at the end of the article
}

\section{$\triangle B M C$}

(c) The Author(s) 2021. This article is licensed under a Creative Commons Attribution 4.0 International License, which permits use, sharing, adaptation, distribution and reproduction in any medium or format, as long as you give appropriate credit to the original author(s) and the source, provide a link to the Creative Commons licence, and indicate if changes were made. The images or other third party material in this article are included in the article's Creative Commons licence, unless indicated otherwise in a credit line to the material. If material is not included in the article's Creative Commons licence and your intended use is not permitted by statutory regulation or exceeds the permitted use, you will need to obtain permission directly from the copyright holder. To view a copy of this licence, visit http://creativeco mmons.org/licenses/by/4.0/. The Creative Commons Public Domain Dedication waiver (http://creativecommons.org/publicdomain/ zero/1.0/) applies to the data made available in this article, unless otherwise stated in a credit line to the data. 